\title{
FILMES NA FORMAC̣ÃO DE FUTUROS PROFESSORES: EDUCAR O OLHAR
}

Laura Noemi Chaluh*

RESUM0: Neste artigo, trago parte de minha experiência como professora de futuros professores de Matemática quando ministrei a disciplina Didática, no ano de 2010. Socializo aqui algumas das práticas instituídas nesse contexto e que resgatam a potencialidade dos filmes e da escrita no processo formativo dos alunos. Problematizo a importância de "assistir juntos" a um filme, já que essa experiência estética possibilita promover o conhecimento, o sentimento e a ação. Trago a voz dos meus alunos, documentada nos registros semanais elaborados por eles, para dizer das "marcas" que os filmes deixaram no percurso formativo de cada um como futuros professores de Matemática. Ao resgatar essa prática, enfatizo a importância de "educar o olhar" na busca pela constituição de um professor comprometido com uma educação e uma sociedade mais justa e democrática.

Palavras-chave: Formação de Professores. Filme. Prática Pedagógica.

\section{MOVIES IN THE DEVELOPMENT OF FUTURE TEACHERS: TEACHING ONE TO LOOK}

ABSTRACT: In this paper I share some of my experiences as a teacher trainer at a college for Mathematics teachers, where I taught the subject area "Didactics", in 2010. I offer some of the practices that were put in place in the duration of that training. These (practices) bring to the fore the potential of movies, written works in the process of training students. I highlight the importance of watching a movie together because the aesthetic experience shared, permits a growth in knowledge and feelings and inspires action. I bring the voices of my students, documented in their weekly records, to show the "marks" (or impressions) left by the movies on each one's developmental path, towards becoming a mathematics teacher. In highlighting this practice, I emphasize the importance of "teaching to look", in the quest for well-educated, committed teachers and in the bringing-about-of a more just and democratic society.

Keywords: Teacher Education. Movies. Educational Practice.

* Doutora em Educação pela Faculdade de Educação da Universidade Estadual de Campinas (UNICAMP) e Professora Assistente do Departamento de Educação na Universidade Estadual Paulista Júlio de Mesquita Filho (UNESP, Rio Claro) e do Programa de Pós-Graduação em Educação do Instituto de Biociência da Universidade Estadual Paulista Júlio de Mesquita Filho (UNESP, Rio Claro). E-mail: Ichaluh@rc.unesp.br 


\section{Introdução}

Neste trabalho, socializo parte de minha experiência como professora de Didática, na Licenciatura em Matemática. A disciplina é anual e os encontros ocorrem semanalmente. Destaco que ela é oferecida no terceiro ano do curso e que, só nesse momento, os alunos iniciam estudos específicos relacionados com as questões educativas.

A turma estava constituída por 21 alunos, que, desde o primeiro dia de aula, inquietaram-me com suas respostas sobre o que concebiam em relação ao que era a Didática. Algumas das respostas registradas no meu caderno dizem de uma concepção técnica dessa disciplina. Segundo a maioria dos alunos, a didática trataria os seguintes aspectos: "como ensinar", "ter bagagem para passar para os alunos" "como explicar o conteúdo", "ter facilidade para passar matéria para o aluno", "para dar aula", "aprender a ensinar", "métodos e maneiras de ensino", "métodos de ensinar", "como agir", "como passar informação para os alunos". Poucos apontaram para questões que, não necessariamente, tinham a ver com "passar o conteúdo", e suas preocupações estavam atreladas a querer saber "como enfrentar os problemas com os alunos" e "como prender a atenção do aluno".

No primeiro encontro, ficou instituída a prática do registro. Essa prática tinha por objetivo que os alunos começassem a olhar para a sala de aula, para o grupo que estávamos constituindo. Implicava reconhecer que, nesse contexto, era possível perceber acontecimentos relacionados com as relações interpessoais, com o tipo de comunicação que poderíamos estabelecer, com os papéis que cada um de nós poderia assumir, etc.

Assim, desde o primeiro dia, foi colocada a importância da observação e do registro. Todos nós iríamos fazer o registro de todas as aulas. Essa escrita poderia conter descrições dos acontecimentos vividos na sala, impressões, sensações, sentimentos, em definitivo, o que nos tinha "tocado", "acontecido" nesse encontro (LARROSA, 2004). Para isso, resgato a ideia de experiência, segundo o mesmo autor, "é o que nos passa, o que nos acontece, o que nos toca [...]. Walter Benjamin, em um texto célebre, já observava a pobreza de experiências que caracteriza o nosso mundo. Nunca se passaram tantas coisas, mas a experiência é cada vez mais rara" (LARROSA, 2004, p. 116). No início das aulas, eram socializados os registros de alguns alunos e também o meu. 
Valorizo essa prática de registro nas aulas com meus alunos, já que foi algo vivido por mim em uma disciplina da universidade, na minha própria formação. Isso, na época, permitiu-me mudar meu olhar: 1) olhar mais aprofundado sobre a sala de aula; 2) perceber que, frente a um mesmo acontecimento compartilhado, nossos olhares eram diferenciados; 3) um olhar, uma observação e um registro vinculados com a reflexão.

Essas considerações sobre a prática do registro importam, pois é a partir dos registros sistematizados por meus alunos, alguns dos quais serão apresentados aqui, que problematizo a importância de "assistir a filmes junto com" nossos alunos, seja na universidade, seja na escola. Essa prática, instituída por mim nas minhas aulas, mostra-se como provocadora para ampliar o olhar, a percepção, o sentir e o pensar sobre a educação e para promover a ação dos futuros professores. Nesse sentido, enfatizo a importância de "sensibilizar o olhar" ou "educar o olhar" dos nossos alunos, futuros professores, pelas implicações que isso tem no processo formativo.

\section{Sobre os filmes no contexto da sala de aula}

Alguns teóricos enfatizam a importância de legitimar, no contexto da sala de aula, tanto o conhecimento científico quanto outros aspectos da cultura - teatro, música, artes plásticas -, já que, como considera Kramer (2003), eles possibilitam tecer relações com a emoção, o corpo, a criação.

Na mesma linha, Guimarães, Nunes e Leite (2002), ao tratarem da formação do profissional da educação, consideram que

a formação deve erigir-se banhada na cultura, contemplando experiências com artes plásticas, música, teatro, fotografia, cinema, museus, literatura, dentre outras. O profissional não é um objeto no qual se devam depositar conceitos e esperar respostas adequadas; ele é sujeito cidadão do mundo que tem direito ao conhecimento, à reflexão, à escola, à expressão (2002, p. 170).

Garcia e Alves (2002) estabelecem um diálogo a partir de suas próprias experiências com a formação de futuros professores e fazem uma crítica aos modelos de formação (não só na área de educação). Nesse diálogo, a segunda autora considera que estamos inseridos em uma socie- 
dade "na qual a questão cultural é considerada como menor, quase exótica" (p. 110). Os cursos de formação nem sempre percebem a "necessidade de uma visão mais ampla de sociedade, condição para a formação de uma professora como, hoje, é indispensável" (p. 110).

A crítica da autora mostra que o espaço/tempo da sala de aula não é suficiente para uma formação que permita compreender a complexidade do mundo. É preciso apresentar atividades que envolvam a questão cultural, porque, para essa autora, "não se trata de formar o pesquisador somente, mas de reconhecer no sujeito da prática essa capacidade de interrogar a realidade em que vive, tanto quanto sua própria prática, colocando-a em contato, sempre, com o mundo todo, interrogando-o, no mesmo movimento" (2002, p. 110).

No mesmo diálogo, a primeira autora considera que é fundamental incluir no currículo "oportunidades de ampliação do universo cultural de nossos alunos e alunas" (p. 110-111). Considera que

vivemos numa sociedade perversa, que discrimina e exclui e que o processo de exclusão não se dá apensas sobre os bens materiais, mas também sobre os bens simbólicos, que foram historicamente privatizados, impedindo ou, pelo menos, dificultando a nossos alunos e alunas de a eles terem acesso (p. 111).

$\mathrm{Na}$ minha prática pedagógica, na formação inicial e continuada de professores, tenho instituído a utilização de filmes nas aulas. Foi a partir de minha própria experiência que, em outros momentos (VARANI; CHALUH, 2008; CHALUH; VARANI, 2009), conseguimos problematizar questões relacionadas com a importância dos filmes no contexto de formação de professores.

Assim, o uso de outras linguagens nos cursos de formação, entre eles, os filmes, enfatiza a importância de considerar a formação cultural e estética (MIRANDA, 1998; OLIVEIRA JR., 1999; NAPOLITANO, 2003; TEIXEIRA, 2003; DUSSEL, 2006; PALADINO, 2006; BOLOGNINI, 2007).

Para Miranda (1998, p. 15),

O estudo das imagens nos leva a pensar a articulação de saberes, conhecimentos, percepções, emoções e memória que a "psique" (alma) humana movimenta quando olha para elas. Em vista disso, a aprendizagem, enquanto tema educacional torna-se mais complexa - histórica e cognoscível. Esta experiência permite a emersão de dimensões humanas geralmente esquecidas pelas 
teorias da aprendizagem: o inconsciente, a imaginação, os mitos, os arquétipos, os deuses, o sagrado.

Para esse autor, alguns riscos aparecem quando são introduzidas as obras de arte na sala de aula. Isso porque, segundo ele, elas podem entrar como ilustração ou como recurso didático, esquecendo sua dimensão de objeto cultural. Ainda aponta ele que podemos descartar a linguagem artística porque não é científica e, dessa forma, a tornamos mera ilustração, e não produção.

Segundo Dussel (2006), as imagens não deveriam ser um recurso para ensinar o mesmo de sempre. A autora enfatiza a necessidade de considerar as imagens como um objeto e condição de nossa existência, ou seja,

artefactos que nos atraviesan como personas y como ciudadanos y que atraviesan y configuran nuestras formas de saber. Son formas de representación de la experiencia, son formas de conocimiento, y no puertas o ventanas que nos conducen al verdadero conocimiento que proporciona la escritura (2006, p. 284).

Oliveira Jr. (1999) faz uma crítica àqueles que tratam os filmes no contexto escolar como "textos a serem lidos e compreendidos parte por parte" e considera que os mesmos teriam de ser compreendidos como "textos a serem vistos e sentidos como um todo" (p. 170). Reforça essa concepção ao considerar que as pinturas e os filmes não têm como objetivo contar algo como realmente ocorreu ou como realmente é; as pinturas e os filmes "querem apresentar uma experiência humana" (p. 170).

Oliveira Junior (1999) considera que o filme na escola nos permite conversar "sobre aquilo que ele diz a mais do que o que estava no programa" (p. 174). E, nesse sentido, pensando naquilo que o filme nos leva a dizer a mais do que estava explicitado no programa, Varani e Chaluh (2008) trazem a conceptualização da experiência estética: "O encontro estético do sujeito com o objeto, no caso, o filme, implica que o primeiro se abandona à obra o que significa: deixar-se emaranhar pela obra, deixar-se envolver por ela...” (p. 9).

Segundo as autoras, a experiência estética promove dois tipos de leitura: a leitura estética e a leitura didática. A leitura estética é "aquela na qual o sujeito convidado a assistir ao filme toma seu referencial de vida, seu pro- 
cesso histórico, e a partir deles se vê mobilizado a produzir sentidos, os que surgiram a partir da relação estabelecida com essa experiência vivida" (VARANI; CHALUH, 2008, p. 10). Também, Oliveira Jr. (1999, p. 171) considera que, ao assistir a um filme, nos envolvemos com o que foi visto na tela, criamos vínculos afetivos com um ou vários personagens, assumimos como nossas as angústias das personagens, assim como suas dores e alegrias.

Sobre a leitura didática, Varani e Chaluh (2008, p. 11) destacam: "quando o sujeito que assiste ao filme tece diálogos com os autores e perspectivas teóricas tratadas na disciplina e que lhe permitem ampliar as compreensões relativas às questões específicas da mesma". Assim, quando essa experiência estética acontece na escola, na sala de aula, ela está atravessada por um objetivo didático, com uma intencionalidade. Como apontam as autoras, após assistir ao filme há uma discussão sobre ele, o que promove "uma racionalização desta compreensão, desta vivência estética" (p. 11). Nesse sentido, considera-se que uma das formas de ler um filme é a leitura didática, porque ela está atrelada a um objetivo.

Assim, a experiência estética de assistir a filmes, quando possibilitada no contexto da sala de aula, é um elemento provocador para aquele que assiste a ele. E, como já assinalado, essa tal experiência promove e potencializa diferentes formas de ler, sendo que tanto a leitura estética quanto a leitura didática possibilitam o tecido de redes de sentidos, sensações, compreensões, reflexões e, juntas, permitem ampliar a leitura e interpretação sobre uma problemática.

Segundo Paladino (2006), ao assistir a um filme ou fragmento do filme temos de fazer uma apresentação informando: o que é que vai se ver, para que e qual o objetivo de assistir a essa produção. A autora afirma que não fazer essa breve apresentação pode provocar desconcerto e incerteza. Por outro lado, ela considera que "como todo texto, el fílmico puede ser leído en múltiplos sentidos. Orientar esa lectura, anticipando el eje que se quiere seguir no implica elidir los demás significados sino dejarlos en latencia para darles su entrada en el momento oportuno" (PALADINO, 2006, p. 141). Ou seja, dar informações, antecipadamente, sobre o filme de nenhuma forma está delimitando as possibilidades de construção de sentidos próprios sobre o encontro do sujeito com essa produção, como já explicitado anteriormente. 


\section{Educar 0 olhar: questões políticas e pedagógicas}

A partir dos registros elaborados pelos meus alunos, gostaria de discutir, neste momento, a importância da educação do olhar, pois essa discussão traz, para todos nós, formadores de futuros professores, reflexões para pensar quais as nossas práticas pedagógicas em relação ao uso da imagem na sala de aula e qual o sentido de educar o olhar dos nossos alunos como dimensão formativa política.

Para isso, dialogo com Dussel' (2006), que discute a importância das imagens e sua relação com as políticas e práticas pedagógicas a partir de uma proposta de elaboração de materiais audiovisuais que foram subsídios para desenvolver um trabalho sobre a diversidade e a discriminação junto com professores e alunos.

Segundo Dussel (2006), esse trabalho baseou-se em três pressupostos teórico-pedagógicos:

En nuestras sociedades crecientemente fragmentadas es necesario intervenir sobre la formación ética e ciudadana para contribuir a generar identidades sociales y prácticas políticas y culturales inclusivas, democráticas y no discriminatoria.

Que esa formación no tiene solamente componentes intelectuales-racionales sino que también se apoya en sensibilidades y disposiciones éticas y estéticas, en cuya configuración desempeñan un papel relevantes los relatos y las imágenes que proveen de los medios de comunicación de masas (DUSSEL, 2006, p. 278, grifos meus).

É nesse sentido que a autora enfatiza a promoção de uma alfabetização midiática ou audiovisual na "formación de una ciudadanía más igualitaria y con mayores niveles de acceso y participación en la cultura y la esfera pública" (DUSSEL, 2006, p. 278).

A questão central discutida pela referida autora é em relação a "cómo se educa la mirada" (p. 287). Ela nos leva a pensar nas formas de produção de políticas e pedagogias da imagem, para, assim, discutir quais os atuais usos da imagem e qual a formação política que se depreende desse uso.

Uma questão fundamental e recorrente no trabalho de Dussel (2006) é pensar o que se faz com as emoções que são despertadas pelas imagens. A autora encontra algumas respostas no diálogo com Sontag ${ }^{2}$ (2003), quando esta última considera que é justamente a partir das emo- 
ções despertadas pelas imagens que existe a possibilidade da reflexão ética e politica, e é nesse contexto que o trabalho educativo deveria se focar e aprofundar.

Parece fundamental dizer que para poder dar conta das emoções que as imagens nos provocam é preciso considerar qual a relação que temos estabelecido com os outros:

Parece que se hubiera olvidado de que la relación con otros se apoya también en sensibilidades y disposiciones éticas y estéticas, en dejarse conmover, en poder escuchar otras historias. También en poder juntar estas historias con otros saberes, en cruzar lo singular con lo universal, en poder pensar reglas más complejas y más interesantes para los desafíos que nos presenta la vida en común (DUSSEL, 2006, p. 288).

E ainda, Dussel (2006) pergunta-se qual o sentido de trabalhar com as imagens. E, mais uma vez, apoia-se em Sontag (2003) para encontrar respostas. Esta última autora, no referido livro, fala das fotografias de guerra e, a partir dessas imagens, pergunta-se o que fazemos frente à dor dos outros. Dussel (2006) questiona:

Para que mostrar el dolor de los demás? Buscamos la compasión, la piedad, o algún otro tipo de acción? Mas aún, en este mundo tan saturado de imágenes, cada una más impactante que otra, como evitar que se banalice el dolor? Cómo sentirnos tocados cuando vemos a alguien con hambre, a alguien herido, a alguien desamparado, si las imágenes rápidamente le dan paso a la siguiente noticia impactante y no podemos hacer nada? Como volver a conmovernos? (DUSSEL, 2006, p. 290, destaque meu).

Dussel (2006) dialoga com Sontag (2003), que considera que a saturação de imagens impactantes, sem nenhum curso de ação, nos produz uma espécie de anestesia, de apatia e que, por isso mesmo, é preciso trabalhar em três níveis:

el del conocimiento (entender por qué sucedió lo que sucedió, ponerle nombre, identificar responsabilidades), el de la emoción (poder sentirnos conmovidos por la imagen, sentir que hay un plano humano que universaliza ese dolor y lo hace también propio, aunque sea de otro y nunca lleguemos del todo a saber qué siente el otro) y el de la acción (la posibilidad de hacer algo para repararlo). Volver a conmovernos, y a reflexionar y a actuar sobre esa base: hay aquí algunas pautas importantes para el trabajo pedagógico (DUSSEL, 2006, p. 290-291). 
As considerações de Dussel (2006) são fundamentais para se compreender o movimento gerado no interior do meu grupo de alunos quando enfrentados às imagens trazidas pelos filmes. O diálogo com essa autora ainda contribui para nos questionar: que professores estamos formando?

\section{Do encontro dos meus alunos com os filmes/documentários}

No percurso da disciplina, tive a possibilidade de assistir, junto com meus alunos, aos seguintes filmes e documentários: Pro dia nascer feliz; ; Escritores da liberdade ${ }^{4}$, Entre os muros da escola ${ }^{5}$, Vista sua pele e Boneca na mochila?.

Faço aqui uma escolha dos registros dos meus alunos para deixar em evidência as proposições colocadas por Dussel (2006) sobre o trato das imagens na formação como possibilidade para vincular o conhecimento, a emoção e a ação e, ainda, para pensar nas disposições éticas e estéticas.

Por isso, faço a escolha de mostrar três momentos. Em um primeiro momento, trago acontecimentos registrados por meus alunos após assistir ao filme Pro dia nascer feliz. Aponto que esse filme foi um grande provocador de emoções e que, frente a tantas inquietações, decidimos juntos que, no próximo encontro, iríamos tentar definir algumas ações para perceber, como professores, até onde poderíamos trabalhar a questão da violência no contexto escolar.

O segundo momento traz os registros dos meus alunos após terem a experiência de viver um Horário de Trabalho Pedagógico Coletivo (HTPC). Lembro que, após terem assistido ao documentário Pro dia nascer feliz, ficaram tocados e angustiados com algumas questões: a violência na escola e a morte de uma adolescente. Assim, propor desenvolver um HTPC tendo como pauta a problematização da violência na escola permitiu que eles refletissem sobre as possibilidades e limitações de ação que poderiam encaminhar, caso fossem, de fato, professores de uma escola.

Em um terceiro momento, trago os registros dos meus alunos após terem assistido a Escritores da liberdade. A intencionalidade de ter socializado esse filme com eles foi motivada pelo fato de que, nos encontros que antecederam esse dia, o discurso de alguns alunos era "de que nada era possível", "a educação não tinha saída", "só existem barreiras com as quais não podemos fazer nada". Frente a esse discurso, 
pensei que esse filme seria uma mostra de que ainda existem algumas possibilidades.

Ao trazer as vozes dos meus alunos, vejo a importância que as imagens tiveram como desencadeadoras para a reflexão. E, mais uma vez, enfatizo que podemos pensar no encontro com o filme, tanto pensando na experiência estética - leitura estética e leitura didática - (VARANI; CHALUH, 2008) quanto como considerado por Dussel (2006), como instância que permite que os alunos tenham acesso ao conhecimento, à emoção e à ação, na busca pela promoção de disposições éticas.

Não pretendo fazer uma análise dos registros dos meus alunos. Eles falam, dizem, gritam, sugerem, sussurram suas subjetividades, suas histórias pessoais, suas emoções, seus pensamentos, seus desejos e seus medos. Os registros são potentes para deixar em evidência a força dos filmes no contexto de formação.

A questão da ação me parece fundamental que seja vivenciada ainda na formação inicial, oferecendo possibilidade para que eles, os nossos alunos, desenvolvam ações coletivas, favorecendo sua autonomia e participação na gestão e na resolução de problemas. Isso porque, como considera Davini (1999), os futuros professores têm de vivenciar um novo modelo na formação inicial, já que, no momento da inserção como docentes na escola, é difícil que ocorram mudanças. É só no exercício do diálogo e da participação efetiva na ação que podemos promover na formação inicial de professores que assumam a gestão da escola. Seguem os escritos dos meus alunos. ${ }^{9}$

\section{Primeiro momento: 0 encontro com o filme Pro dia nascer feliz}

\section{REGISTRO DE NATALIA}

A aula deste dia foi muito diferente, pelo menos para mim, a começar pelo local em que ela aconteceu, pois o local era desconhecido para todos nós e ficamos admirados com o fato de ser algo novo e bem mais confortável do que as salas que estamos acostumados. [...]

Emocionei-me em várias partes do filme, fiquei pensando no papel do professor retratado em cada fala dos alunos, e percebi que o docente tem um papel muito importante na vida de cada aluno. Sempre pensei que ser professor é uma grande responsabilidade, pois estamos lidando com pessoas e que nossas atitudes podem ajudar ou não.

[...] fiquei muito triste com a situação de pensar que nossos sonhos e esfor- 
ços na faculdade podem ser inúteis em meio a tantos problemas e que a profissão de professor tem muitas vezes se confundido com a função de pais e mães, que cada vez mais estão distantes da vida de seus filhos. E constatar que isto tem contribuído para que muitos professores se desanimem com a profissão. Mas ao mesmo tempo penso que assim como a professora de Literatura pode proporcionar à aluna, que não queria viver, um sentido de vida, pelo menos por aquele momento em que estava na escola, é algo muito gratificante, e que é realmente isto que faz com que professores como ela continuem exercendo a profissão.[...]

Durante a discussão do filme, foram apontados muitos problemas, mas penso que a escola não funciona para "robozinhos", pois são pessoas que fazem parte de uma sociedade e, portanto, não podemos evitar ou ignorar que os problemas desta sociedade "entrem" na escola. Nosso papel é lidar da melhor maneira possível com esta situação.

\section{REGISTRO DE ANDREA}

Hoje foi uma aula especial. Assistimos a um documentário superinteressante "Pro dia nascer feliz". [...]

Em outra parte do filme, fiquei assustada, quando uma das professoras relatou que fazia terapia uma vez por mês, pois ela acabava se envolvendo muito com os problemas de seus alunos e que muitas vezes ela não dava aula por cansaço. Ela disse também da pouca importância e da falta de dignidade da sua profissão perante a sociedade, pois são obrigadas a fazer e a aceitar as coisas impostas pelo governo.

Foi aí que comecei a pensar "até que ponto vale a pena ser professor no Brasil, principalmente de escolas públicas?”. Ganhar mal, não ser valorizado, se envolver com problemas avulsos, ser constantemente cobrada, sofrer risco de violência. Afinal, é isso mesmo que eu quero ser? Professora?

[...] Eu quero ser professora, mas não qualquer professora. Quero fazer a diferença para alguém. Só espero não me arrepender dessa minha decisão futuramente.

\section{REGISTRO DE HENRIQUE}

Esta aula foi dez! Assistimos a um ótimo documentário chamado "Pro dia nascer feliz". Gostei muito do documentário principalmente pelo fato de mostrar os valores das pessoas do nordeste. Acho que como sou nordestino, fiquei feliz em ver que existem alunos muito talentosos na minha terra, e ainda despertando admiração nos colegas da minha sala. Por outro lado, o documentário exibe a precariedade das escolas da região. Este fato inspirou minha vontade de ser professor.

\section{REGISTRO DE LUIZ}

Através do documentário, pudemos perceber que a escola, atualmente, tem um forte papel na questão da cidadania. Um exemplo disso foi um aluno que 
encontrou na música um meio de se livrar do crime e das drogas. Essa questão gerou muita polêmica na sala, pois até onde chega o papel da escola? Será que o governo passou essa tarefa para a instituição que deveria gerar conhecimento?

\section{REGISTRO DE FÁBIO}

Um momento que considerei muito importante nessa aula foi quando uma de nossas colegas, ao comentar um trecho do filme em que se identificou, se emocionou. Isso foi uma situação real em que pudemos observar a relação de todos. Tive a impressão de que todos, não sabendo como reagir, ficaram em silêncio. Até mesmo a professora, por alguns instantes, parecia não saber o que fazer, mas deixando a colega desabafar, pôde aos poucos se colocar e ter domínio da situação. Eu não saberia o que fazer no seu lugar.

\section{Segundo momento: a constituição do HTPC}

\section{REGISTO DE GABRIELA}

Por fim, a professora sugeriu que escolhêssemos uma problemática apresentada no documentário e simulássemos uma reunião, em forma de HTPC, para discuti-la.

Decidimos discutir sobre o fato que achamos mais marcante no documentário, onde uma aluna assassinou a outra no próprio ambiente escolar.

No início, não sabíamos como agir, pois a maioria de nós não conhecia esse tipo de reunião.

Depois de alguns minutos, como ninguém se prontificou em assumir o cargo de coordenadora pedagógica, acredito que por não saber claramente como agir em tal cargo, a aluna Natalia se propôs a assumi-lo e iniciou a reunião sugerindo que discutíssemos como evitar que tal episódio acontecesse novamente.

Achei essa prática de grande experiência e confesso que não havia notado quantas propostas sugerimos para o tema abordado.

Em minha opinião, enquanto professores, não podemos deixar de refletir se fazemos uso da violência, tanto verbal, quanto física, em nossa sala de aula.

\section{REGISTO DE FÁBIO}

Decidimos fazer a simulação de uma reunião onde os professores (nós alunos e a professora) tinham que decidir o que fazer diante da situação, vista por nós no documentário, em que uma aluna é esfaqueada e morre dentro da escola. Eu e mais alguns alunos apenas assistimos sem participar, mas a maioria se envolveu na simulação. Surgiram algumas alternativas, acho que a que mais se destacou foi a necessidade de dialogar com os alunos. Acho que os maiores resultados foram percebidos pela professora que já tem um olhar mais amplo das discussões. 


\section{REGISTO DE NATALIA}

Acabei me propondo a ser a coordenadora e confesso que não sabia ao certo como agir. Propus o que achava que seria importante ser feito mediante um acontecimento como este, pensar em um modo de evitar que isto ocorra outras vezes. Sei que não é uma tarefa fácil, pois não depende somente da escola, mas assim como falei acho que não podemos deixar de tentar.

Muitas propostas foram feitas. Acho que foi uma experiência válida, mas um pouco cansativa pelo fato de, como eu estava no "papel de coordenadora", tive que pensar em como as sugestões poderiam ser aplicadas ou não na escola.

Mas acho que esta atividade superou as expectativas de todos, inclusive a da professora, que comentou o que havíamos falado. Eu não tinha percebido o quanto tínhamos propostas e quantas coisas tínhamos pensado com relação à escola.

\section{REGISTRO DE TEREZA}

Colocamo-nos como representantes educadores da escola que passa no documentário assistido, na qual uma aluna mata a outra dentro do ambiente escolar, e iniciamos uma discussão sobre como prevenir que uma tragédia desse nível venha acontecer novamente. [...] mas a melhor ideia que surgiu foi a de que cada professor passasse a conversar e discutir com seus alunos em suas aulas sobre o ocorrido, e abrindo um tempo para que os alunos que quisessem conversar pudessem procurá-los. Pensamos até mesmo em tornar essas conversas um hábito, já que isso não seria bem uma "perda de aula", pois com essas conversas, as aulas poderiam render bem mais que normalmente rende. [...] Acredito que todos tenham escutado e se impressionado com a frase da menina em questão "Matar não dá em nada quando se é menor" e "Três anos passam rápido”. Então, quando o adolescente sente raiva de uma colega ou um professor, por exemplo, como convencê-lo a não ser imprudente, [...] diante da facilidade de se livrar das consequências de seus atos?

\section{REGISTRO DE LAURA (PROFESSORA)}

Esqueci de fazer o registro, apenas saí da sala. O que me chamou a atenção foi o exercício reflexivo que surgiu a partir do HTPC, encontro de professores que a Natalia coordenou, apontando a necessidade de buscar ações comuns. Não foi uma comédia, esse termo apontado por Fábio, cada um conseguiu assumir um lugar de professor e todos juntos conseguiram procurar saídas para o conflito: desde pensar que um professora da escola fosse "escuta" dos alunos, trazer especialistas para discutir com os alunos, promover assembleias de classe. Mas as discussões foram de extrema importância, eles conseguiram olhar a violência a partir de diferentes perspectivas - a tortura em história, a sexualidade em Educação Física, romantismo na literaturaainda falaram da fragmentação e o tempo mínimo que os professores compartilham com os alunos, a interdisciplinaridade, como fazer para não atrapalhar a aula no sentido de "não perder tempo" com os acontecimentos que surgem no cotidiano. Acho que minha fala no final do exercício foi mais representativa do que agora, na minha escrita. 


\section{0 encontro com o filme Escritores da liberdade}

\section{REGISTRO DE LUIZ}

Creio que esse filme mostrou um possível futuro para nós, pois a qualquer momento podemos nos deparar com uma sala dita "problemática". Na discussão do filme, em meio a vários olhos vermelhos, foi possível perceber que o filme realmente afetou a todos. O debate foi bem produtivo, e nos levou a refletir muito sobre o assunto.

É interessante observar como a professora conseguiu captar o que causa desconforto na sala e sempre traz algo diferente que nos chame atenção e gere discussão.

\section{REGISTRO DE RENATA}

Voltando ao filme, gostei muito da maneira como a professora lidou com os alunos, não sei o que faria frente a uma situação daquelas, mas não acho, como foi discutido em sala, que os conteúdos haviam sido deixados de lado, ali foram passados valores, coisas que estes alunos já tinham perdido, assim como a matéria de uma maneira diferenciada. Fiquei depois pensando como eu agiria em uma sala assim? Será que conseguiria lidar com esses problemas. Deu-me um frio na barriga de pensar nisto, foi uma das primeiras vezes que pensar em entrar na sala de aula como professora me deu medo, não pelo que os alunos poderiam ser, mas o medo do desconhecido, talvez não seja um medo, mas aquela curiosidade com um friozinho na barriga.

\section{REGISTRO DE ANDREA}

Este filme foi muito emocionante. [...]

Adorei ver a força com que a professora luta para melhorar a vida de seus alunos. Esse filme mexeu muito comigo, pois ele mostrou o tipo de professora que queria ser. Emocionei-me com a história de cada aluno, com a luta da professora contra o sistema e o sucesso da sua vida profissional.

[...] Eu espero ter a força e a luz que esta professora teve para eu conseguir o melhor para meus alunos. Meu sonho é conseguir me entregar de corpo e alma para uma sala, podendo unir a sala e acabando com o preconceito existente entre os alunos da mesma forma com que ela fez. Mas sei que para conseguir essa utopia é preciso coragem, inteligência, afeto, força e amizade entre os alunos e o professor, e isso é muito difícil. Temo não conseguir e desistir no meio do caminho.

\section{REGISTRO DE NATALIA}

Pude perceber o quanto é importante a relação entre professor e aluno para que a aprendizagem aconteça, e que também se faz necessário conhecer a "realidade" dos alunos.

Também pude perceber o quanto a escola pode "influenciar" e também reproduzir o que acontece na sociedade, ela não é um lugar perfeito, onde os 
problemas, convicções, culturas e costumes são deixados para fora dela. Embora o filme pareça, de certa forma, "utópica", e que dificilmente todos os professores conseguiriam agir desta maneira sempre, com todos os alunos, podemos pensar em como poderíamos fazer alguma coisa por nossos alunos, pensando que embora muitos encarem o ser professor como um "trabalho" apenas. Mas este trabalho assim como outros, tem sua responsabilidade e deve ser encarado como tal.

[...] Acho que a aula de hoje, assim como a aula em que foi passado o documentário, foi uma das melhores aulas para mim, pois gosto de pensar em situações em que posso "utilizar" os conhecimentos "teóricos" e refletir sobre ser professor e a importância de ser um professor comprometido e, na medida do possível, contribuir não para mudar o mundo, mas pra fazer a mudança em um aluno, em uma classe, em uma escola.

\section{Algumas conclusões}

Para meus alunos, as imagens têm provocado tanto emoções quanto pensamentos sobre as várias facetas da vida de professor e da educação. No último dia de aula, solicitei a escrita de uma avaliação final acerca do percurso da disciplina, tentando fazer uma análise de todos os acontecimentos compartilhados, das propostas, dos textos. Não foi uma avaliação direcionada no sentido de ter de responder pontualmente alguns intens. Eles ficaram à vontade para dizer os aspectos que haviam sido positivos e negativos no trabalho realizado. Dos 21 alunos, sete lembraram dos filmes/documentários:

Maria: O que ficou de bom das aulas de didáticas para mim, foram principalmente os filmes e documentários que me fizeram refletir muito sobre o que escolhi para minha vida.

Marina: Todos os filmes ilustraram muito bem a parte teórica da disciplina e mostraram realidade que podemos encontrar no nosso dia a dia.

Joyce: Estava me esquecendo dos filmes, eles foram muito legais de assistir, em muitos me emocionei, só que o último que assistimos me desmotivou um pouco. Erica: Não esquecendo dos filmes, que não deixa de ser importantíssimo para a reflexão, pois ele mostra "a realidade" para nós que por enquanto acredito que não conhecemos. Uma das discussões que me marcou foi quando assistimos aqueles documentários sobre preconceito. Aonde discutimos sobre a realidade do Brasil e pude perceber que tem muitos alunos que precisam viver mais a prática.

Renata: Os filmes foram muito importantes, junto com eles eu pude refletir e ter a certeza da profissão que estou seguindo, o quando desafiador e prazeroso é dar aulas. 
Tereza: Os filmes e documentários, todos perfeitamente escolhidos, me emocionaram muito. Me alertaram para coisas que sabemos que são verdadeiras, mas que preferimos não pensar nelas. Achei importantíssimo cada um dos filmes que vimos. O que mais gostei foi "Pro dia nascer feliz", esse documentário mexeu muito comigo.

Luiz: A ideia dos filmes e documentários foi excelente, por ser uma abordagem diferente dos textos discutidos em aula, tendo, na minha opinião, maior impacto sobre a turma.

Reflexão, emoção, realidade, profissão, impacto... Com certeza, o "impacto" dos filmes nos meus alunos foi provocativo, em todos os sentidos abordados neste texto. Destaco, mais uma vez, a importância dos mesmos também na questão ética, isso porque as imagens fizeram com que eles se pensassem como futuros professores e, a partir desse lugar, problematizassem "que professor/a de Matemática quero ser?" Coloquei essa pergunta desde o primeiro dia de aula e sempre nos reportávamos a ela nas discussões e leituras. Essa pergunta leva, necessariamente, a pensar: Qual o comprometimento com a educação? Qual a responsabilidade de assumir o lugar do professor?

Mas, neste momento, gostaria de enfatizar que para poder conhecer o que "aconteceu" com cada um dos meus alunos, a partir do encontro com os filmes/documentários, a escrita apareceu como uma dimensão fundamental. A escrita apareceu como possibilidade de rememorar os acontecimentos vividos por eles. No começo, ficavam com dúvidas e não sabiam muito bem o que dizer, o que não dizer, o que apontar... Em alguns momentos, senti que pediam auxílio para que eu pautasse a escrita, como se existisse uma forma "correta" de expressar opiniões e emoções perante os acontecimentos compartilhados por todos nós. A escrita, para muitos dos meus alunos, apareceu com força, era uma escrita sentida, era uma escrita na qual era preciso se deter para pensar (LARROSA, 2006).

Gostaria de finalizar trazendo um diálogo com Larrosa, já que ele traz contribuições para pensar no que ele chamou de professor-escritor. Segundo Larrosa (2006)

Escribir es una de las formas que tenemos para estar atentos al mundo y a lo que nos pasa. Escribir forma parte de una tentativa para ser parte del mundo de una forma más reflexiva, más consciente, más plena, más intensa. Escribir forma parte de ese esfuerzo, nunca garantizado, por estar presentes en lo que nos pasa. 
O mesmo autor considera que na escrita da experiência o que importa são os sentidos que damos aos acontecimentos. O que "nos aconteceu" nos leva a pensar e a escrever. É a partir da experiência que, ao deixar suas marcas no papel, nos fala alguma coisa. Muitas vezes essa escrita diz coisas que anteriormente não havíamos percebido.

Larrosa (2006) aponta a necessidade de pensar no professor como escritor. Trago essa afirmação do autor, pois guarda estreita relação com a força das imagens/filmes considerados neste trabalho. Isso porque, em definitivo, com a escrita e com as imagens/filmes estamos apontando a educar um olhar ou a sensibilizar um olhar capaz de perceber ao outro, capaz de se comover perante a presença do outro.

Como considera Larrosa (2006, p. 4), "podría pensarse, entonces, tal vez, en algo así como el educador como escritor que trata de elaborar y de compartir, en la escritura, el sentido o el sinsentido de lo que le pasa, tratando de que la escritura le ayude a estar atento al otro".

Para finalizar, destaco, mais uma vez, as falas de Dussel (2006, p. 278), para quem a formação, quando atravessada pelas imagens, é uma formação que "no tiene solamente componentes intelectuales-racionales sino que también se apoya en sensibilidades y disposiciones éticas y estéticas". 


\section{Referências}

BOLOGNINI, C. Z. (Org.) O Cinema na escola. Campinas: Mercado de Letras, 2007. CHALUH, L. N.; VARANI, Adriana. Escola, professores e alunos: cinema em cena. II CONGRESSO INTERNACIONAL COTIDIANO - DIÁLOGOS SOBRE DIÁLOGOS. Universidade Federal Fluminense (UFF), Niterói, Anais..., 2008.

DAVINI, María Cristina. Formación docente, análisis y perspectivas. 1999. Disponível em: <http://www.internet.com.uy/aphu/formacion_profes.htm>. Acesso em: dez. 2006. DUSSEL, Inés. Educar la mirada. Reflexões sobre uma experiência de producción audiovisual y de formação docentes. In: DUSSEL, Inés; GUTIERREZ, Daniela (compiladoras) Educar la mirada: políticas y pedagogías de la imagen. Buenos Aires: Manantial: Flacso, OSDE, 2006.

GARCIA, Regina Leite; ALVES, Nilda. Conversa sobre pesquisa. In: ESTEBAN Maria Teresa; ZACCUR, Edwiges (Orgs.). Professora-pesquisadora: uma práxis em construção. Rio de Janeiro: DP\&A, 2002.

GUIMARAES, Daniela; NUNES, Maria Fernanda Rezende; LEITE, Maria Isabel. História, cultura e expressão: fundamentos na formação do professor. In: KRAMER, Sonia; LEITE, Maria Isabel; NUNES, Maria Fernand; GUIMARÃES, Daniela (Orgs.) Infância e educação infantil. 2 ed. Campinas, SP: Papirus, 2002. (Coleção Prática Pedagógica) KRAMER, Sonia. Por entre as pedras: arma e sonho na escola. 3 ed. São Paulo: Ática, 2003. LARROSA, Jorge. Experiencia y alteridad en educación. Buenos Aires: FLACSO, 2006 Disponível em:

<http://virtual.flacso.org.ar/mod/book/print.php?id=3908>. Acesso em: 16 mai.2006. LARROSA, Jorge. Notas sobre a experiência e o saber da experiência. In: GERALDI, Corinta M. Grisolia; RIOLFI, Claudia R.; GARCIA, Maria de Fátima (Orgs.). Escola Viva: elementos para a construção de uma educação de qualidade social. Campinas, SP: Mercado de Letras, 2004.

MIRANDA, Carlos E. A. Ver filmes, dizer educação, olhar cultura. Revista de Educação, PUC Campinas, v. 3, n. 5, 1998.

NAPOLITANO, Marcos. Como usar o cinema na sala de aula. São Paulo: Contexto, 2003. OLIVEIRA JR., Wenceslao Machado de. Filmes \& Professores: Momentos de uma oralidade muito presente. Pro-Posiçôes, v. 10, n.1, março 1999.

PALADINO, Diana. Que hacemos com el cine em el aula. In: DUSSEL, Inés; Gutierrez, Daniela (compiladoras) Educar la mirada: políticas y pedagogías de la imagen. Buenos Aires: Manantial: Flacso, OSDE, 2006.

SONTAG, S. Ante el dolor de los demás. Buenos Aires: Alfaguara, 2003.

TEIXEIRA, Inês Assunção de Castro; LOPES, José de Sousa Miguel. 2 ed. A escola vai ao cinema. Belo Horizonte: Autêntica, 2003.

VARANI, Adriana; CHALUH, L. N. O uso do filme na formação de professores. ETD - Educação Temática Digital, Campinas, v. 10, n. 1, p. 1-23, dez. 2008. 


\section{Notas}

1 A proposta procurou contribuir com a alfabetização midiática de docentes e alunos, "enriqueciendo su capacidad de leer de otros modos las imágenes, buscar otras relaciones con la palabra, y trabajar sobre sus disposiciones y sensibilidad hacia las estéticas y los contenidos del lenguaje audiovisual masivo" (DUSSEL, 2006, p. 279).

2 SONTAG, S. Ante el dolor de los demás. Buenos Aires: Alfaguara, 2003.

3 O filme trata da relação do adolescente com a escola, focando também a desigualdade social e a banalização da violência. Mostra o cotidiano escolar de uma região extremamente pobre, em Pernambuco, outra no Rio de Janeiro, em São Paulo, uma em Itaquaquecetuba (SP) e uma escola de elite de São Paulo. Dirigido por João Jardim e Walter Carvalho (BRASIL, 2002).

4 O filme é baseado na história real de Erin, uma professora novata interessada em lecionar Língua Inglesa e Literatura para uma turma de adolescentes estigmatizados como os "sem-futuro". Diretor e roteirista Richard LaGravenese (2007).

5 Trata da realidade do cotidiano escolar de um professor de língua francesa em uma escola de Ensino Médio, localizada na periferia de Paris. O diretor é Laurent Cantet (2008).

6 Criado pelo MEC a fim de abordar a questão do preconceito racial. Nesta história invertida, os negros são a classe dominante e os brancos foram escravizados. Secretaria de Estado de Educação de Paraná.

7 A protagonista foi chamada porque flagraram seu filho com uma boneca na mochila. Durante o caminho, enquanto ouvem um programa de rádio sobre homossexualidade, eles conversam sobre esse assunto. ECOS - Comunicação em Sexualidade.

8 Meu agradecimento aos alunos citados, que me autorizaram a socializar suas falas.

Recebido: 13/04/2011

Aprovado: 12/09/2011

Contato:

Universidade Estadual Paulista Júlio de Mesquita Filho Avenida 24 A, 1515

Bela Vista

CEP 13506-900

Rio Claro, SP

Brasil 
